\title{
Art Appreciation for Developing Communication Skills among Preschool Children
}

Matjaž DUH ${ }^{1}$

$\approx$ In the contemporary process of teaching fine arts, children's own creative expression and art appreciation are used to encourage learners towards both perception and reception; consequently, the evaluation and internalization of works of art play an equally important role. In a qualitative empirical research study that takes the form of a case study, we studied the response of children to works of art and their demonstrated communication skills in this. The results have shown that children respond to works of art on multiple levels. With non-standardized narrative group interviews, we observed children's associations. Children perceived and internalized the given artworks and also put their emotions into words. The study has shown that systematic development of art appreciation among pre-school children can have a positive impact on their communication skills.

Keywords: communication skills, art appreciation, visual art, preschool education 


\section{Likovna apreciacija $v$ funkciji razvijanja komunikacijskih sposobnosti predšolskih otrok}

Matjaž DuH

$\approx$ V procesu sodobnega pouka likovne umetnosti imata enako pomembno vlogo lastno ustvarjalno izražanje otrok in likovna apreciacija, pri čemer se učeči srečajo tudi s percipiranjem in recipiranjem, torej z vrednotenjem in s ponotranjenjem umetniških del.

V kvalitativni empirični raziskavi, ki ima obliko študije primera, smo preučevali odzivanje predšolskih otrok na umetniška dela in pri tem izkazane komunikacijske spretnosti. Ugotovili smo, da se otroci na umetniška dela odzivajo na več ravneh. $\mathrm{Z}$ nestandardiziranim narativnim skupinskim intervjujem smo spremljali asociacije otrok. Otroci so prikazana umetniška dela zaznali in ponotranjili ter svoje občutke tudi ubesedili. Raziskava je pokazala, da sistematično razvijanje likovne apreciacije pri predšolskih otrocih lahko ugodno vpliva tudi na njihove komunikacijske sposobnosti.

Ključne besede: komunikacijske sposobnosti, likovna apreciacija, likovna umetnost 


\section{Introduction}

In the preschool period, giving children experience in a range of fields is extremely important for their overall development. "Listening to music, for example, the child develops her or his ear, repeats the words they hear, probably also moves with this, thus developing many diverse abilities. Listening to fairy tales and watching illustrations children develop their vocabulary, they develop imagination and the capacity of longer concentration" (Duh, 2013, p. 33). Several opportunities thus exist for using various branches of art for the development of the child's cognitive, affective, and psychomotor areas. It depends on the teacher whether, in the process of artistic creative activity, children will develop their potential to the maximum; whether they will develop new skills through varied methods and forms of learning; and whether they will know how to observe, interpret, perceive, and thus develop their competences. Especially in the case of observing works of art, the teacher's guidance is indispensable (Duh \& Kljajič, 2013). As a school subject, however, art develops competences not only in the area of children's creative abilities, but also in the area of perceptive and receptive abilities, which means appreciation competences. Under the term "art appreciation," we understand perceiving and reception based on emotions and experiencing the visual in works of art (Duh, 2004). It is, then, about the kind of reflection that must develop "in close association with producing and receiving and must be cultivated with creating and understanding paintings" (Regel, 2001, p. 70, quoted from Schütz, 2002, p. 123). Research (Duh, 2004; Kraguljac \& Karlavaris, 1970) has shown that both creative and appreciative abilities are a matter of quantity, which means that all normally developed children possess these capacities. Contemporary teaching of art is thus conducted in two directions: (1) developing creative abilities in art (productive), and (2) understanding fine art (perceptive).

Bertscheit (2001) maintains that locating works of art into the interest area of learners is a primary goal of teaching art. This is why it is extremely important for preschool teachers' performance of the education process to include observation of works of art. Teachers must be able to establish communication between children and the work of art. The attitude of the child towards a work of art must be seen from two points of view. On one side is the child's innate feeling for visual order, and on the other side the acquired feeling for the beautiful and aesthetic (Zupančič \& Duh, 2009). Today we know that art appreciation is not innate, but is an ability that can be developed with appropriate educational work (Duh, Čagran, \& Huzjak, 2010). 


\section{Art appreciation and the development of communcation skills}

Encouraging the development of art appreciation should begin sufficiently early, believes Payne (1990), who feels that younger students need a creative approach to the development of art appreciation. One needs to be aware that younger children in preschool are still too little and cannot use appropriate terminology. This can produce a rather low level of art appreciation as a consequence (Duh, 2013). With four-year-old children, Coates (1993) detected appreciation at an elementary level when they described a range of objects. As evidence of appreciation in its early phase, she identified children's responses such as the following:

"That's big" in relation to size, "It's snowy" in response to a blossom tree and "It's smooth" after stroking a pebble" (Coates, 1993, p. 252). In these talks, in which children use imagination "they often generate a flow of creative ideas which can spill over into other parts of the curriculum. The impractical ones can always be rejected later on, leaving the best ideas for discussion and modification" (Barnes, 2002, p. 135).

Children describe not just things related to the works of art, but everything they see around them. Teachers can use this as a stimulus, by offering children other new experiences and thus systematically developing and widening their word power. Teachers should give children assistance in recognising the quality of objects, to lead them actively and attentively from articulating what they feel, to developing the appropriate vocabulary for describing these feelings (Duh \& Zupančič, 2013). Imaginative conversation conducted in this way can additionally activate the child's thinking and also help with other fields of learning. Many creative ideas are developed that interweave with the contents of other subjects (Barnes, 2002). Children must first notice works of art in order to be able to enjoy them and talk about them on a subsequent occasion. This is why art activities in preschool must encouragechildren to acquire techniques for observing aesthetic objects. In her research, Coates found that in some cases children "looked for things that were familiar but at other times they used their imagination to try and decide exactly what each painting was about" (Coates, 1993, p. 260). If we wish to develop the capacity for appreciation in children, then talking about their perception is fundamental, since discussion with children offers teachers rich feedback. "The process of looking and questioning has an added bonus for the teacher," says Barnes and adds, "Together, teacher and child can talk in terms which build a vocabulary 
for looking at things. Both of them sharpen observation by sharing what they themselves see" (Barnes, 2002, p. 141). With adequate incentives, children will acquire the ability to describe what they have seen. In a study involving preschool children, Aylward et al. (1993) discovered that initial differences in art experience among children of different ages were reduced, while differences between genders disappeared completely. The literature identifies those procedures through which children learn to see. "Watching," says Berger, "denotes a relatively passive action of looking at," and continues, "seeing points to an act of looking for and reading meaning in the viewed, i.e. to an active interpretation of the seen" (Berger, 2008, pp. 7-8). Through an open approach to works of art, visual abilities and organised observation, as well as mental, emotional and other activities are developed in children. "Aesthetic objects require recipient's openness for frequently unusual effects of motifs and materials, composition, colours, rhythms and tones" (Kirchner et al., 2006, p. 12). For the process of developing art appreciation, Pagany (1993) establishes four phases: (1) perception of a visual work with all senses, (2) releasing emotions, (3) converting images into speech, and (4) action. The first three levels give precedence to the reception of images, while the fourth phase requires production. For conversation about works of art, Barnes proposes four useful questions: (1) "What do you see? (Description); (2) How are things put together? (Analysis); (3) What is the artist trying to say? (Interpretation); (4) What do you think of it? (Judgement)" (Barnes, 2002, p. 145). Discussion with children about original artwork or reproductions offers opportunities for them to learn some special words for describing these works. Children learn to use words like form, colour, and line, provided teachers use these with sufficient frequency.

\section{Definition of the research problem}

In this study we monitored preschool children's reactions when presented with works of art and thus observed their perceptive and receptive abilities, and therefore their visual appreciation abilities. The procedures and processes of observing and receiving works of art are a good starting point for planning the observation of adult artists' artwork during art activities in preschool and while visiting galleries.

In the study we started from the fact that appreciation is accessible to everyone, although not to the same extent, and that it is an ability that needs to be and can be developed within the education process and systematically brought closer to children. "To develop appreciation it is important the perception of artworks is more than just watching and quick reaction; it must be a 
meaningful experience. Observation must lead to interaction between the child and the work of art, where sensory stimuli get directly attached to memory, experience, emotions, and associations" (Duh, Zupančič, \& Čagran, 2014, p. 213). Associations allow integration of various representations and depend on common features and similarities such as external form, colour, line or composition. Because associations are subjective and frequently biographically adopted, adequate conditions must be established in the group, to allow children to express their personal opinions without fear. Because of their personal perspectives and associations, these will differ for each child. "At this their perspective of vision will escalate the experience of other learners and thus also stimulate the development of art appreciation abilities in them (Duh, 2004, p. 47). The teachers who perform the teaching of art must be aware that different children react to the same work of art in different ways; it is important, however, that each should react to the same work in more than one way. There are three ways of responding: (1) response at the emotional level is manifested in an emotional response to the work of art being evoked in viewers; (2) response at the associative level refers to associations which are raised in the observer on viewing the work of art, and (3) response at the formal intellectual level refers to responses that appear with viewers after formal analysis and interpretation of the work of art (Arts Education, 1996, Viewing Art Works). These three types of responses oscillate and change from viewer to viewer and from one artwork to another. This, someone might immediately respond in an emotional way, while someone else responds at an intellectual level. A work of art can, however, also trigger an immediate emotional response with most observers, while another work evokes associations in viewers (Duh et al., 2014).

\section{Methods}

The purpose of the empirical research was to examine the response of preschool children to a work of art and the communication skills demonstrated within this activity. Within this framework, we seek to answer the following research questions:

- What associations will children have upon discovering artwork?

- In what way will they describe what they see?

- In what ways will the children get to know and experience the given artwork?

- Will the children learn to observe a work of art, perceive, accept and internalise it and also to put their feelings into words? 


\section{Research methods}

The qualitative empirical research takes the form of a case study. It is based on the interpretative paradigm and an ideographic approach (Peez, 2005). The research was conducted in several phases in which children systematically and gradually learnt about various works of art. For the collection of data, the non-standardized narrative group interview was applied, in which we were not limited by predetermined questions but allowed children to say what they saw and thought was important. This kind of interview was selected because it is the most similar to everyday conversational situations among people, since we wished to create a relaxed research atmosphere for viewing the works of art. The participants in the study were informed that the conversations would be recorded.

In the research we applied the technique of document analysis, which is unobtrusive and non-reactive (Vogrinc, 2008), as a supplementary data gathering technique. The documents are represented through photographs taken during various phases of the research.

\section{Research sample}

The relevant purposive sample for the empirical research consisted of eleven children, 5 to 6 years old; of these 7 were boys (63.6 \%) and 4 girls (36.4 $\%)$, who were selected from among the oldest children in the preschool at Tezno in Maribor (Slovenia). The conversations were conducted in the media room on 2 April 2015 between 12:20 and 13:40. Apart from the children and the researcher, the teacher was also present during the research interview. For easier communication, the children were divided into two groups (of 5 and 6 children); the research procedure was thus repeated twice. We selected purposive sampling. In the front of the research, was the relevant knowledge of visual art, of those involved in the process of preschool education?

\section{Preparation of instruments and conduct of research}

The research instruments consisted of a presentation programme (Microsoft Power Point), audio recording of the conversation and occasional photos taken during the research process. The presentation programme consisted of 73 slides with photographs of artworks by six Slovenian artists, along with basic information about the artists and their work. Given the findings about preferences in art motifs from a gender perspective (Duh \& Herzog, 2012) we 
used visual artworks with various motifs in the study. Since research (Duh, Herzog, \& Ros, 2013) has shown that it is not just the motif, but also visual elements, colours, forms, composition, etc. that influence the attitude towards visual artwork, we selected diverse works of art for the use in the study.

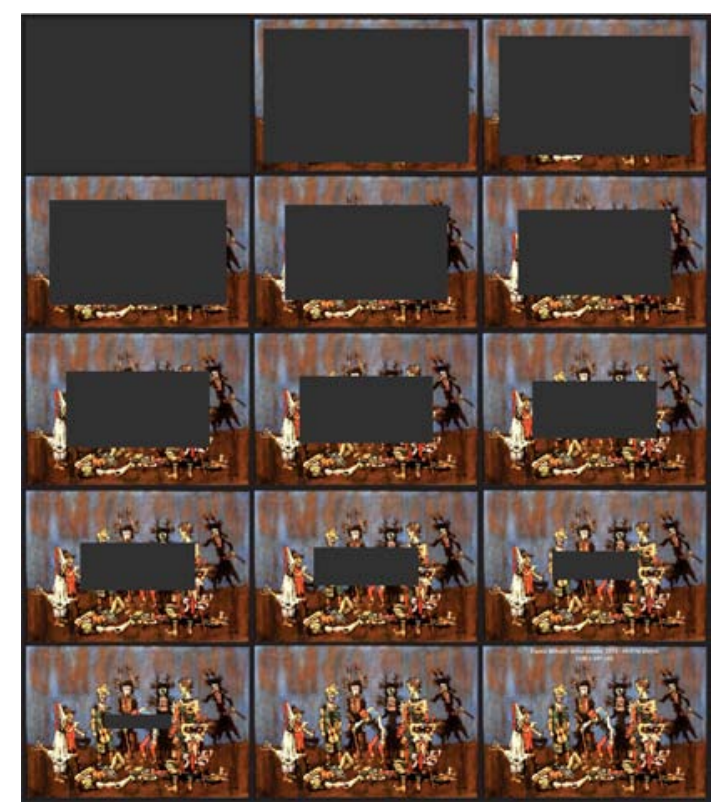

Figure 1. Presentation of the gradual uncovering of a work of art (F. Mihelič, Mrtvi kurent)

In the first stage, we gradually uncovered the painting Mrtvi Kurent (The Dead Kurent, France Mihelič, 1973, acrylic on canvas, 100 x $147 \mathrm{~cm}$ ). The painting was masked in grey in a shade identical to the background of the screen image (Figure 1). We uncovered the painting in 15 steps from all four outer margins inward, while (zoom) taping (audio recording) the children's observations. We adapted the pace of change for the sequence of images to the dynamics in the group of children. In the second stage, the painting Trnovo pozimi (Trnovo in Winter, Rihard Jakopič, 1924, oil on canvas, 51 x $70 \mathrm{~cm}$ ) was masked behind a translucent grey that we brightened in 10 consecutive steps until the final revelation. In the third stage, the children gradually got acquainted with the painting Portret očeta (Father's Portrait, Marij Pregelj, 1953, oil on canvas, 116 x $88.5 \mathrm{~cm}$ ). We removed the grey cover from the image simultaneously from the left and right margins in 14 steps. In the fourth stage, the children gradually got to know the abstract painting Babilonski fragmenti (Babylon Fragments, Azad Karim, 2010, 
acrylic on canvas, $110 \times 130 \mathrm{~cm}$ ). As with the second stage, we brightened the translucent greyness slowly in 11 steps. In the fifth stage, the children were progressively acquainted with Avtoportret (Self-Portrait, Janez Logar, 1971, acrylic on canvas, $179.5 \times 137 \mathrm{~cm}$ ). This time, at the beginning, the children saw only a white rectangle the size of the painting. Within it, the artwork emerged by degrees in 15 steps, from above and from the right. In all phases the pace of change for the consecutive images was adapted to the dynamics in the group of children. In the sixth stage, the children became familiar with the painting Poletje (Summer, Ivana Kobilica, 1889-1890, oil on canvas, $180 \times 142 \mathrm{~cm}$ ). They saw the whole painting in the very first slide. They subsequently learnt about the author, at the third screen slide, the title of the artwork and with the fourth, the date of its creation. In the fifth screen image the children were also informed about its size, and in the sixth, they received all the remaining data. The children viewed the projected images while seated in front of the projection screen. To guarantee the validity of the non-standardized narrative group interview, we registered all the conversations, which will be presented in detail below. Thus, all the interpretations will have support in the collected material. For interpretation, we analysed the interviews according to the characteristics of the quality analysis, starting from transcription. Since this study was not focused on the way the children expressed themselves, but only on the content, we used the paraphrased form of transcription and copied the responses in accordance with orthographic rules of written language, yet as faithfully to the original as possible (Vogrinc, 2008).

\section{Data processing procedures}

The data gathered from the interviews were analysed using qualitative content analysis, which was conducted in two phases: (1) paraphrased transcription of audio recordings, (2) interpretation with the formulation of theory according to the research questions.

In the qualitative research, ethical practice was observed in all its aspects: voluntary participation in the study; informed participation; protection of individual identity; confidentiality and privacy, and respect for truth.

\section{Results and interpretation}

We gradually learnt about the artworks by five authors and talked about them with the children in both groups. The responses of children to the works being gradually uncovered were quite spontaneous. Each further step in revealing the artworks triggered new responses. Initially, these were to the large part 
at the intellectual level and referred primarily to what could be seen thus, to the motif. Later some children associated the scene with their experiences, and so we could also talk about responses at the associative level. We observed emotional responses by some children in intermediate reactions, or upon perceiving the painting as a whole and during its internalisation. Owing to restrictions of space, we will present only some of the essential reactions of children and part of the paraphrased transcription of the group interview.

On presentation of the first painting, Mrtvi kurent (France Mihelič), the children quite quickly recognised the lying figure, first its face and then the kurent (a traditional Slovenian carnival figure) on the right of the painting. The attention and responsiveness of the children were remarkable. After further uncovering of the artwork, some associated the scene with the carnival and denoted figures as positive or negative. "That one hit him, so he fell on the ground," stated one child. The kurent scene evoked associations with a fight; a reaction was therefore triggered at the associative level. The children further named some of the depicted figures, e.g.: "How funny this one is!" for a costumed figure on the left the painting or, "What a funny hat!" pointing to one of the figures. When the last slide gave the title of the masterpiece, the question followed, "Why did he die?" Another child's answer was, "Because that one hit him." One of the children stood up and, pointing a finger at the supine figure, guessed who might have hit him. "This one hit him," indicating the figure standing with his back towards the viewer. When they heard that kurents chase winter away and that in doing this one of them had become exhausted, the response of the majority of the children changed. Spontaneous reactions such as "Poor kurent," or "How sad," demonstrate that the painting had aroused an emotional response in the children. In response to the question what colours they saw in the painting, the children pointed to most of the colours and named them. When they were told that the width of the painting was nearly a metre and a half, they showed with their arms how wide it was. The procedure for developing art appreciation by systematic uncovering of the artwork produced good results with children of this age. In each group the gradual uncovering of the painting and the accompanying conversation took about six and a half minutes. The intensity of the communication and active participation extended the attention span of children, who observed the changes on the screen throughout the presentation. The children experienced the painting and also knew how to verbalize their feelings.

At the next stage the children became acquainted with Rihard Jakopičs painting Trnovo pozimi. During the gradual thinning of the grey veil over the picture, they recognized trees in the lines in the foreground, while associating the forms in the background with various things: “That's a ship." In the second group of children, the response differed from the second slide: "I know what I 
see. Snow, and houses," or, "I see fences, and trees, and landscape, and a road." The children stood up from their seats and pointed to the screen. At each new step, they wanted to show and tell what they had discovered. In this case, too, the responses were mainly at a formal, intellectual level. In the next observation phases the associations expressed in the comments were similar in both groups. They also related the scene to the season: "It is winter, because there is snow and it is a sunny day." To the question why, the answer followed: "Because there is a lot of sunshine; the picture is yellow." They designated other colours as light or dark. "A lot of snow has fallen, because it is all over the houses;" they pointed to very bright parts of the painting. Thus, they linked their own associations with the scene. At this point, they enumerated the seasons and observed that at the time of experiment spring. Because of the relatively realistic depiction of this motif, the presentation of this work of art only took four minutes, but with the children, it evoked a positive reaction. Such a method for developing art appreciation stimulated interesting communication and lively developments, including rushing towards the projection screen, as nearly all the children wished to tell and show where and what they had discovered. The children experienced and internalised the painting and expressed their feelings both verbally as well as with gestures.

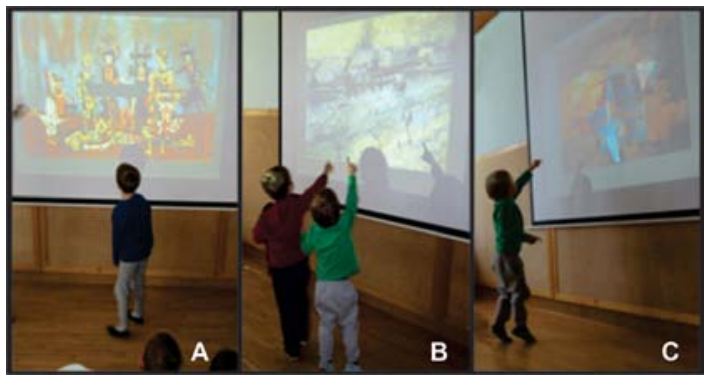

Figure 2. Children exploring paintings by France Mihelič (A), Rihard Jakopič (B) and Azad Karim (C).

As the third artwork, the children of both groups explored Marij Pregelj's painting Portret očeta. Below, we present a paraphrased form of the recording of the conversation. We labelled the researcher's questions and conversational prompts as R, while the letters A, B, C, D, E and F denote the reactions of the six children in the second group. In the first slide the reproduction was completely covered. In the next slide only the left and right margins could be seen.

"R.: This image is different, though? What can we see here?

A.: I see something. A stone and something red. B.: And I see some dirt. C.:

This is an uncle. A.: I know what's there. 
R.: What?

A.: And there's a little more dirt behind. D.: I know what it is. Perhaps it's the kind of picture where the world cannot move.

R.: Perhaps. Let's go on and see what is hidden underneath.

C.: It's a sort of chair, perhaps. D.: This is something broken. A.: I know, I know. Perhaps this cannot move, perhaps they look like birdhouses, or something. R.: Shall we reduce this greyness a bit further, so we can see more? What can we see now?

B.: I know now. D.: I know. B.: Maybe it's a man sitting down.

R.: Where?

B.: Maybe he's sitting on the chair. C.: Maybe it's a wall.

R.: Right, and what do you say?

E.: Perhaps it's a house. F.: Perhaps they are city walls. A.: I know what it is. Perhaps this is a house and a car behind or something like that." (Group interview II. A-F/15, P-10:15 to 12:46). ${ }^{2}$

In this part of the conversation, which took about two and a half minutes we gradually uncovered the artwork in four stages. The children stood up from the bench, approached the projected reproduction and underscored their statements by pointing. Since the largest part of the picture was covered, the visible parts of it evoked a range of associations in the observers. The reactions of the children were spontaneous and the associations personal, as in one case they were influenced by familiar forms, in another by colours that could be perceived. At this part most of the children were actively participating in the conversation, with two needing additional prompting.

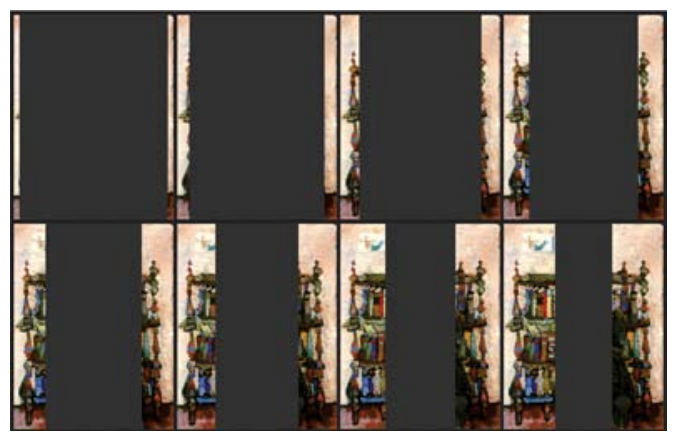

Figure 3. Gradual uncovering of the work of art. Portret očeta (M. Pregelj). The first eight phases.

2 The numbers in parentheses refer to the transcription of the whole conversation. They are read in the following way: it concerns the second (II) group of children A-F that was carried out in 2015; the paraphrased form of transcription $(\mathrm{P})$ was carried out with the time of the recording between minutes 10:15 and 12:46. 
Below we present how the conversation unfolded between the researcher and the children in the next four phases of uncovering the work of art:

"R.: Let's watch some more. Sit down and let's observe the picture well. What could this be?

B.: It's a bookshelf.

R.: A bookshelf? Where did you see a bookshelf?

B.: Here. E.: And I see a cupboard. It's a cupboard.

R.: What do you say?

F.: It's a kind of chair made of blocks. C.: And I see it looks like a cupboard with books on.

R.: All right, we can go on. He said he saw a cupboard on which there are books.

A.: And I think it looks like a table.

R.: And you think it is a table. Right. Let us look some more, so we can see what it is. Now you tell what you can see.

B.: It's a bookshelf. C.: Yes, I know what it is. It's a table and there's something on it. B.: Yes, it's a bookshelf. A.: Like a bookshop. A colourful bookshop.

R.: We will reduce this greyness a little more. Let's see what we can observe now.

A.: It's a house, and a roof, and there's another above there.

R.: Well, now you too say what you can see (encouraging the two children who had been more reserved).

E.: This is could be a bookshelf, or, perhaps also something else. F.: It's like there are books piled up." (Group interview II. A-F/15, P-10:15-12:46).

After the eighth stage of the presentation, we can conclude that, for some children, associations linked to form have passed into identification of the subject. The previous act of guessing had already achieved a more concrete perception and for some children, a response at the associative level had become a response at the formal, intellectual level. The communication was very lively and the children identified with the conversation. At each new uncovering of the artwork, a child stood up, occasionally several children at a time, and pointed to a newly revealed image in the painting. They became so absorbed in the uncovering of the artwork that they seldom remained seated in their places. 


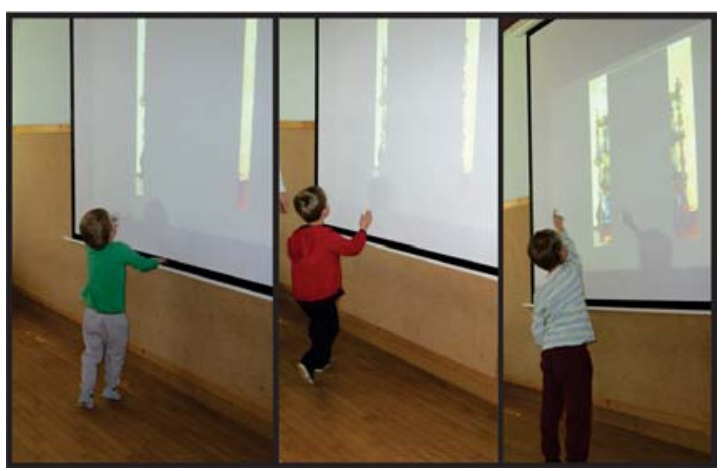

Figure 4. Children observe, explore and describe the visible part of the artwork.

We will now present how the conversation proceeded between the researcher and the children in the next four phases of uncovering the artwork:

"R.: Shall we continue looking? Right, let's go on.

C.: Now I can already see something up there.

R.: Yes, what do you think will be here? Shall we look a little further? Right, now you say what you can see.

C.: A bear in front of a bookshelf.

R.: Aha! So now we know it's a bookshelf. And this is a bear?

C.: Yes, a bear. B.: I know. An animal who's come to the library, well, maybe it's another bear or a fox. Or something.

R.: Now I'd like to know something. What would an animal be doing in a library? What would an animal do at a bookshelf? Well, let's look some more. A.: Yes, if it found anything. I know already what it is. Like an animal. E.: And I think this is a lady sitting in the library disguised as a bear.

R.: Yes, interesting. And what do you think?

F.: I think it's a monkey.

R.: Right, shall we go on? Let's see what will be revealed.

B.: I know now. E.: Go on one more time. B.: Yes, I know, I know." (Group interview II. A-F/15, P-12:47 - 16:21).

At this stage of uncovering the artwork, the painting was nearly entirely visible. The children were able to recognize a shelf with books and increasingly responded at the formal intellectual level. The central, covered part of the painting still evoked various associations and responses at the associative level. They associated the dark mass in the middle of the painting with a range of animals. The lively response continued, with children getting up and pointing at the newly uncovered images in the painting. 


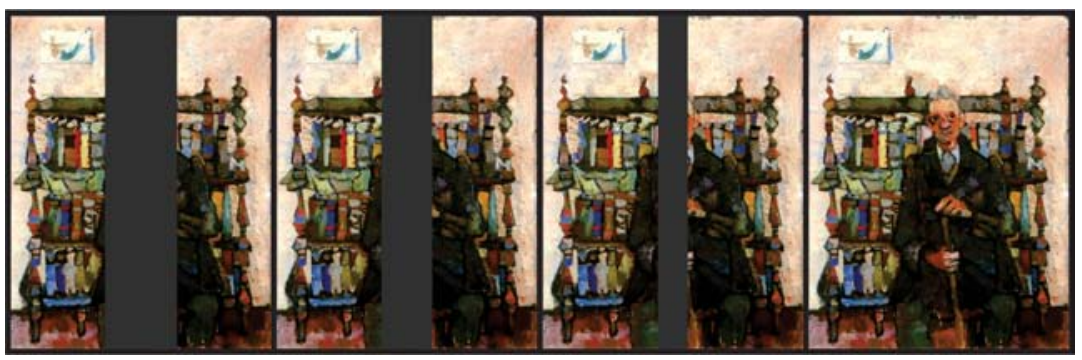

Figure 5. Gradual uncovering of an artwork (M. Pregelj, Portret očeta). Last four phases.

After the twelfth phase of uncovering the artwork, the painting remained covered only by a narrow strip of grey. In the penultimate phase of the presentation, it narrowed even further. We present how the conversation unfolded between the researcher and the children:

"R.: Right. Let's go on. Well, let's take a look.

B.: I know what it is! A man with a hen's head sitting in front of books. A.:

I know this is a man.

R.: Aha! You can see it's a man. Shall we look to the end? (last slide)

A.: Yes, it really is a man (joy)! C.: It's a man in front of a bookshelf.

R.: This is the image the artist painted. What do you think - who did the painter paint?

B.: I'd like to say something. The librarian.

R.: The librarian? Who else could the painter have painted? Who do you draw? Who do you love and you draw them?

C.: Mummy.

R.: Mummy? Is this a mummy?

C.: He drew a gentleman who is choosing books, and he painted him.

R.: Well, before you said mother. Who else could it be, if it is not a mother?

D.: I know. Grandpa. B.: Yes, because this man has exactly the same kind of cane. R.: Shall I tell you what the title of this painting is?

D.: Yes.

R.: Father's portrait. The artist painted his father sitting in front of a bookshelf.

C.: I see he painted something and that he was a painter. D.: I also draw my mother. C.: Me too.

R.: This painter is Marij Pregelj, who painted his father." (Group interview II. $A-F / 15, P-16: 22-18: 07)$. 
The children reported that they, too, had drawn people, while the children in the first group reacted by saying that they had also drawn their family on a walk. In the conversation the children were also informed that photographers take portraits. They observed that most books in the painting were green or blue. "And there's a red one there," a child remarked, standing up from the bench and pointing to a book on the left of the upper shelf.

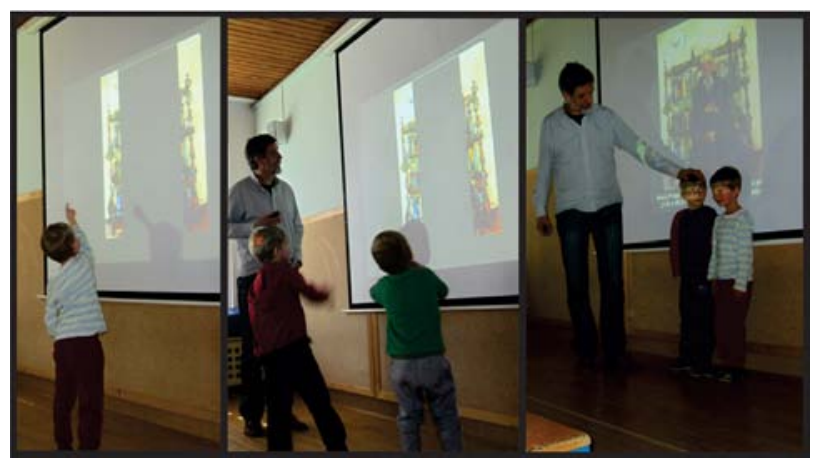

Figure 6. Children observe, explore and describe the visible part of the artwork.

The entire presentation of the painting with this group of children took a little less than eight minutes (7:52). In the first group the conversation about this painting was slightly shorter. We can see from the transcript that the initial response at the associative level developed into a more formal intellectual response. In the process of developing art appreciation, the final uncovering of the painting also evoked a response on the emotional level, as the children linked the content of the painting with their parents. Using characteristic vocabulary, the children also verbalised their internalised feelings.

In the next stage (the fourth) of the study, the children were presented with the painting Babilonski fragmenti (Azad Karim). For the presentation the painting was covered with a translucent film of grey, which we lightened slowly, in nine steps. This was the only abstract painting presented to the children in the study. The children's response demonstrated abundant imagination related to associations. The conversation flowed, and responses such as "I see some hair. This is a ship." or "This is a man with a mask. This is an aeroplane. This is like a car, like a swallow that has eyes like that, and it's smiling" indicate their skill at describing associations. Interestingly, in response to this painting the children in both groups experienced similar associations. In addition to tonal gradation of colour surfaces, the painting is internally structured with graphic symbols. They connected the forms unusual to them with the familiar: 
"If this isn't a crab, it could be a spider." They skilfully verbalised a range of associations, repeatedly rising from the bench to stand in front of the projected picture, while pointing to images. "I see a bridge and also some beads. I see a spider." Describing an abstract painting, without a definable motif, brought them around to describing stories that emerged from their associations. "A little nose, and a spider, eyes, and mouth, and a blanket. And it has little legs. And it fell down and rolled. Here's something, and it cried, and there's some black hair." Via such associations, imagination elicited from the children emotional responses to artwork and to their own explanation of the content. Each of the children in both groups wished to present what they saw. When the painting was gradually uncovered, until completely presented, the children's responses remained close to their initial observations.

The associations "I see three windows and here's an entrance," or "It's such a strange nose. It is so strange, and it has an eye and a mouth. And that spider wants to catch it," indicate exuberant imagination activated by the presentation of the work of art. When the children were told the title of the painting, Babilonski fragmenti (Babylonian fragments) and given a short explanation of the painter's vision of the antique city in Mesopotamia, they mentally kept to their associations: "I see a little dragon." They pointed to bright colours in the middle of the painting and named the colours they could recognise. In each group the conversation took a little over four and a half minutes. With the abstract painting, the procedure for developing art appreciation left considerable room for the children's own interpretation. Using arm gestures, we showed the approximate size of the original painting. The children liked Azad Karim's work of art, which despite the title, left them their own associations; it allowed them their own perceptions, which they could verbalise in their own way.

In the fifth stage the children gradually, in 15 steps, became familiar with Avtoportret by Janez Logar. What they saw at the beginning was a white rectangle the size of the painting, which shrank from the right margin and from the top. In this way the work of art gradually became visible. We will present a summary of the conversation and part of the paraphrased form of the recording from the final stage of the presentation.

The children immediately recognized numbers; only one said, "It's a bird." During the rest of the presentation, they enumerated the numbers they saw in the picture. One of the children enumerated, "Four, five, five four, zero, zero," pointing to the overprints of the numbers. There are no zeros in the painting; the overprints in some places did, however, evoke a similar association with others. From this part of the conversation with the group of children, we can observe the children responding mostly at the formal intellectual level, as they saw only 
numerical signs, and in the second part of the presentation their associations elicited new content. Further conversation dealt with their impression of the condensed and less frequent distribution of numerals in the painting. In a string of condensed numerals the children again recognised a number that does not actually appear in the painting: "There they are in the form of a seven." The children stood up from the bench and showed where the numerals were set more densely and where they saw the seven. With the gradual uncovering of the painting, their associations also became more diverse. "These numbers will make up a picture!” In the raster scheme of dense and infrequent numbers, the child recognised new content. Additional uncovering of the painting only intensified the imagination. "It seems to me it'll be a dinosaur. I see a dinosaur." To the question where he saw the dinosaur, the child ran up to the screen and pointed a finger: "Here's the horn. And here he has a leg, and he's standing kind of this way," and the child assumed a similar pose. In this part of the presentation of the painting, we can conclude that the children gradually passed from response at the formal intellectual level to response at the associative level. From perceiving individual numerals, they passed to their own interpretations.

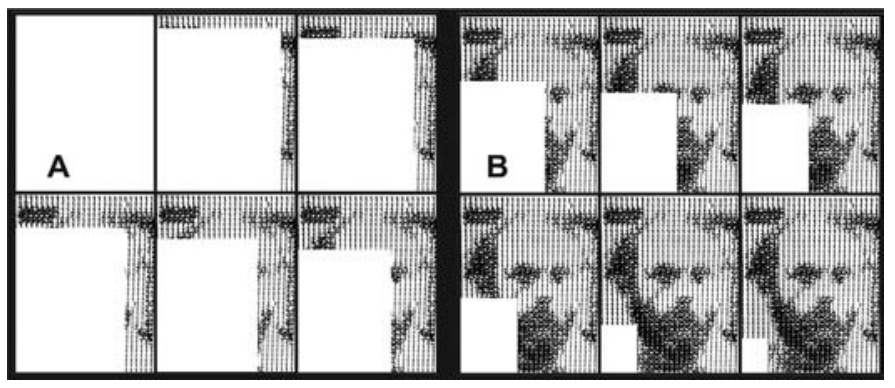

Figure 7. Gradual uncovering of Janez Logar's work of art (first six phases A and six second phases B)

Below we present the paraphrased transcription of the recording made during observation of this artwork. $\mathrm{R}$ indicates questions and conversational prompts by the researchers, and the letters (A, B, C, D and E) designate reactions by the five children in the first group:

"R.: Let us now look a little further. Would you like to know what will emerge from this (presentation of the penultimate painting)? Let's now look with our eyes a little bit closed. Let's have just a tiny look, let's close our eyes a little. What do you see?

B.: I know.

R.: Well, what do you see? Tell us. 
B.: I see an eye, an eye, a smile. A.: There's a dinosaur, he's so strange.. D.: Look, a man, a face. A face (merrily). This is a face. The eyes, mouth, nose. R.: And what do you see? You've been rather quiet.

E.: Some fish, and ......

R.: Show us where you see the fish. Come and show us.

E.: Here are two fishes and here's a dinosaur.

R.: And what do we see if we look at the whole picture?

C.: A head? D.: Our Mayor's head.

R.: Our Mayor's head?

$D$,: Yes (laughter).

R.: And what now? Let's look very closely (presentation of the last phase, the whole painting).

D.: A head. A head.

R.: Do you see one eye, and the other eye, the nose, and the chin, the mouth, the hair?

B.: It's a man. C.: A human face.

R.: This is the way the painter depicted himself. Using only numerals, he composed his face." (Group interview I. A-E / 15, P-5:16 - 7:07)

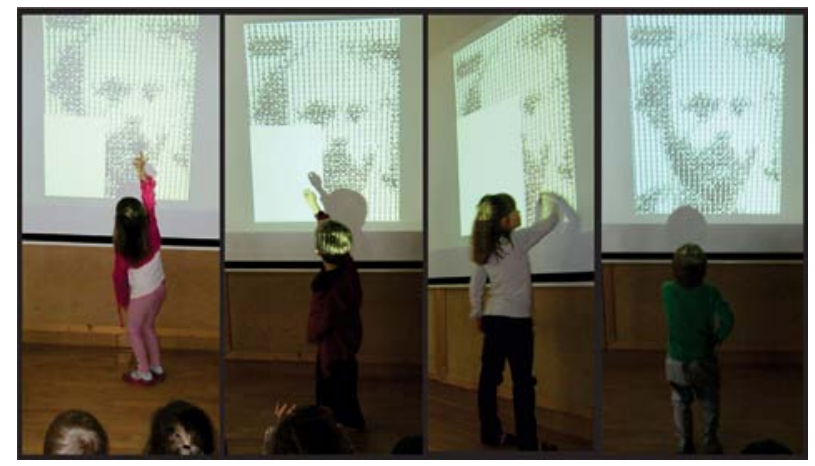

Figure 8. Children uncovering and describing Janez Logar's work of art.

The entire discussion about this painting took a little less than eight minutes. To the question whether they liked the painting, we received affirmative answers. Already familiar with the word portrait (from the discussion of painting \# 3), the children now learnt what a self-portrait represented. In both groups the children reported that the artist had composed the picture from the numbers one to five. The procedure of developing art appreciation also proved to be successful in terms of encouraging communication, since by experiencing the painting fully, the children were able to verbalise their thoughts. The 
intensity of the experience was also evident, as they approached the projected image, because in this way they experienced the scene more intensely and put what their observations into words.

In the last (sixth) phase, the children became familiar with the painting Poletje (Ivana Kobilica). The painting was presented as a whole, with sufficient time to observe it. In response to the question about what they could see, they described the scene: "It's a mother, and there are children," and "Children are playing, and they're playing hide and seek," were the responses on the formal intellectual level. The children were taken by the motif and described it in different ways. When asked whether a man or a woman had painted the picture, the responses were varied: "It's a man", or "A woman" and "A woman painter".

At the next stage of the presentation, they were told who the painter was. The question followed, "Which season of the year is depicted in the painting?" The children linked the painting to the current season. "It's spring!" To the question why they thought it was spring, the answer followed: "Because everything is green." The discussion was oriented around the seasons of the year, and a look through the window of the preschool showed that there were not yet so many leaves on the trees as there were on the trees in the painting. Linking the scene in nature to that in the particular painting led the children to the conclusion: "It is summer." In the next phase the children were told that the title of the painting was Poletje (Summer) and that it had been painted 125 years ago. "Such a long time ago," was the reaction of one of the children. They also learnt that it was a large painting, bigger than they, and they were also encouraged to look once more at what they could see in the picture. "There are five people in the picture." The children limited themselves to describing what was going on in the painting: "The lady is cutting flowers. The boy is picking flowers. A boy is climbing over the fence. The boy has a hat on his head. The lady also has a hat on her head," were all statements made while pointing at parts of the painting. They indicated that the dominant colour in the painting was green, they pointed out the brightest colour (a white dress) in the painting and reported seeing many different flowers of various colours. The description of the painting was extremely lively and took a little less than five minutes in the first group; in the second, it was just over half a minute shorter.

\section{Concluding thoughts}

In this qualitative empirical study, we explored the responses of preschool children to works of art and the communication skills demonstrated during this activity. Diverse procedures of developing art appreciation also evoked diverse 
responses from the children. We found the children responsive to works of art on several levels, depending on the procedure for presentation, on the one hand, and on the work of art, on the other. The paintings with which we carried out the procedure for developing appreciation through gradual uncovering evoked the most diverse associations from the children, ones which they verbalised in their own practical way. In their imagination they played with combinations of parts of paintings, created new links between them, and changed them in such a way as to please their fancy. With additional incentives, the children acquired the ability to describe what they saw. They were clearly able to link the scene to the shapes and colours they knew, as in the discussion the children often used their repertoire of words. Through listening to each other's descriptions of associations, they also enriched their vocabulary. Response at a formal intellectual level prevailed in the case of paintings where a gradual uncovering of a translucent grey film was used in the procedure of developing art appreciation, and in the case of the final painting. They verbalised their observations by describing the motif, the shapes, and colours. In the formal analysis and interpretation of the artwork, appropriate situational language prevailed, given the age of these children. The fourth work of art presented was to some extent an exception, since the abstract painting triggered the most diverse associations and the most idiosyncratic interpretations. Even when they were shown the whole painting, they stuck to their description of the scene. To accompany this painting, contextual speech developed, as the children told whole stories in response to the painting (Starc et al., 2004). Frequently the final uncovering of the paintings also provoked response at the emotional level from most of the children. Thus, the responses of children to works of art passed from one level to another. The procedure: description, analysis, interpretation, and opinion (Barnes, 2002) was partly applied for the development of art appreciation in the last painting.

Children learn by looking at and describing what they see, so we did not expect these children to volunteer many answers regarding the proposed categories. In the discussion we did, however, provide meaning to their associations and linked their observations to the actual content in an unobtrusive way, one that was understandable and acceptable to them. At least equally important is the finding that active ways of developing art appreciation did encourage longer concentration in and activity on the part of children.

In this study we found that children's associations were quite diverse, that they described the scene in their own way, and that procedures for the development of art appreciation were suitable for learning and experiencing works of art. A level of conversation was also achieved, in which all children were included and which enabled development of their ability to verbalize what they had seen. The 
words used in the descriptions were unpretentious, but the aim was achieved of invigorating the child's figures of speech and expression in such a way that they are sufficiently confident to talk about their ideas, as well as to discuss the works of art. This was achieved by having the discussions include the children's previous experience - explained and worded in a way that was consistent with the child's cognitive and emotional development and personal motivation. The movement of children in front of the projections of the artworks, their active comments with interpretation and description of what they had seen the experienced also provide insight into how children identify with a situation and make associations, which are personal and differ from child to child. The task of educators thus remains to find creative ways to realize the content of fine art in accordance with the modern paradigm of art education, which emphasizes as equally important the positive interaction between artistic creation and art appreciation. The resulting outcome should also be visible in other areas of education.

\section{References}

Arts Education (1996). A Bibliography for the Secondary Level. Instructional Resources Unit. Curriculum and Instruction Branch. Retrieved 07.07.2011 from http://www.sasked.gov.sk.ca/docs/ artsed/visart102030/vavwaw.htm

Aylward, K., Hartley, S., Field, T., Greer, J., \& Vega-Lahr, N. (1993). An art appreciation curriculum for preschool children. Early Child Development and Care, 96(1), 35-48 (online). Retrieved 18.04.2011 from http://dx.doi.org/10.1080/0300443930960105

Barnes, R. (2002). Teaching Art to Young Children 4-9. (Second edition). London, New York: RoutledgeFalmer.

Berger, J. (2008). Načini gledanja. Ljubljana: Zavod Emanat.

Bertscheit, R. (2001). Bilder werden Erlebise. Mitreissenden methoden zur aktiven Bildbetrachtung in Schule und Museum. Mulheim an der Ruhr: Verlag an der Ruhr.

Coates, E. (1993). The Language of Appreciation through Talking and Making. Educational

Review, 45(3), 251-262. Retrieved 18.04.2011 from http://www.informaworld.com/smpp/

title $\sim$ content $=\mathrm{t} 71341568 \mathrm{o}$

Duh, M. (2004). Vrednotenje kot didaktični problem pri likovni vzgoji. Maribor: Pedagoška fakulteta.

Duh, M. (2013). Pronalaženje značenja u vizualnoj umjetnosti kao preznačavanja vlastitih govornih konstrukcija. In L. Zaninović Tanay \& E. R. Tanay (Eds.), Sretna djeca - Dijete u razlićitosti izazova. Zagreb: Studio Tanay.

Duh, M., \& Herzog, J. (2012). Preference do likovnih motivov pri učencih prvega triletja osnovne šole. Pedagoška obzorja, 27(1-2), 17-32.

Duh, M., Herzog, J., \& Ros, $\check{S}$. (2013). Preference for visual motifs in first grades of primary school. Innovative issues and approaches in social sciences, 6(3), 92-116. 
Duh, M., \& Kljajič, A. (2013). The level of art appreciation abilities of students in lower primary school grades. Školski vjesnik, 62(2-3), 191-207.

Duh, M., \& Zupančič, T. (2013). Likovna apreciacija in metoda estetskega transferja. Revija za elementarno izobraževanje, 6(4), 71-86.

Duh, M., Zupančič, T., \& Čagran, B. (2014). Development of Art Appreciation in 11-14 year-old Students. The International Journal of Art \& Design Education, 33(2), 208-222.

Duh, M., Čagran, B., \& Huzjak, M. (2010). Quality and quantity of teaching art appreciation.

Croatian journal of Education, 14(3), 625-655.

Kirchner, C., Schiefer Ferrari, M., \& Spinner, K. H. (2006). Ästhetische Bildung und Identität. Fächerverbindende Vorschläge für die Sekundarstufe I und II. München: Kopaed.

Kraguljac, M., \& Karlavaris, B. (1970). Estetsko procenjivanje u osnovnoj školi. Beograd: Umjetnička akademija u Beogradu.

Paganay, D. (1993). Sich Bildern Öffnen. Gedanken und anregungen zur Bildbetrachtung in der Grundschule. Part 2. Grundschulmagazin, 1, 43-5.

Payne, M. (1990). Teaching art appreciation in the nursery school - its relevance for 3 and 4 year olds. Early Child Development and Care, 61(1), 93-106. Retrieved 18.04.2011 from http://dx.doi. org/10.1080/0300443900610112

Peez, G. (2005). Evaluation ästhetischer Erfahrungs- und Bildungsprozesse. Beispiele zur Ihrer empirischen Erforschung. München: Kopaed.

Schütz, H. G. (2002). Kunst und Analyse der Betrachtung. Entwicklung und Gegenwart der Kunstrezeption zwischen Original und Medien. Hohengehren: Schneider Verlag.

Starc, B., Čudina Obradovič, M., Pleš, A., Profaca, B., \& Letica, M. (2004). Osobine i psihološki uvjeti razvoja djeteta predškolske dobi. Zagreb: Goldena marketing, Tehnička knjiga.

Vogrinc, J. (2008). Kvalitativno raziskovanje na pedagoškem področju. Ljubljana: Pedagoška fakulteta. Zupančič, T., \& Duh, M. (2009). Likovni odgoj i umjetnost Pabla Picassa. Likovno-pedagoški projekt u Dječjem vrtiću Opatija. Opatija: Dječji vrtič Opatija.

\section{Biographical note}

Matjaž Duh holds a PhD in art pedagogy and is an Associate Professor of art pedagogy and art didactics at the University of Maribor. He lectures at the Faculty of Education: in the Art Department, the Department for Preschool Education, and the graduate programme for masters and doctoral studies at the Department for Elementary School Education. Within the framework of the programme Erasmus Teaching Staff Mobility, he cooperates with various universities, including Pädagogische Hochschule Wienna, Kunstuniversitaet Linz and Pädagogische Hochschule Viktor Frankl Klagenfurt in Austria; Artesis Antwerpen and Hogeschool-Universiteit Brussel in Belgium; 
Nyugat-magyarországi Egyetem, Savaria Szombathely, Hungary; the Faculty of Education Brno, the Faculty of Art Education in Palacký University Olomouc and the Faculty of Education at the Jan Evangelista Purkyně University Usti nad Labem in the Czech Republic; Sveučilištu Jurja Dobrile u Puli, Croatia, and others. Matjaz Duh is an active researcher. For the last few years, he has been actively researching the use of contemporary media in art education, the development of art creativity and art appreciation, problems of the ongoing paradigm within art education, the development of artistic expression, and other similar areas. He is a member of InSEA (The International Society for Education through Art), where he actively participates in congresses. 